\title{
The Causal Relationship between Unemployment and Inflation in G6 Countries
}

\author{
Suna Korkmaz ${ }^{1, *}$, Muzhgan Abdullazade ${ }^{2}$ \\ ${ }^{1}$ Department of Economics, Faculty of Economics and Administrative Sciences, Bandırma Onyedi Eylul University, Turkey \\ ${ }^{2}$ Department of Economics, Bandirma Onyedi Eylul University, The Institute for Graduate Studies in Social Sciences, Turkey
}

Received July 12, 2020; Revised August 24, 2020; Accepted September 17, 2020

\section{Cite This Paper in the following Citation Styles}

(a): [1] Suna Korkmaz, Muzhgan Abdullazade, "The Causal Relationship between Unemployment and Inflation in G6 Countries," Advances in Economics and Business, Vol. 8, No. 5, pp. 303 - 309, 2020. DOI: 10.13189/aeb.2020.080505.

(b): Suna Korkmaz, Muzhgan Abdullazade (2020). The Causal Relationship between Unemployment and Inflation in G6 Countries. Advances in Economics and Business, 8(5), 303 - 309. DOI: 10.13189/aeb.2020.080505.

Copyright $\mathrm{C} 2020$ by authors, all rights reserved. Authors agree that this article remains permanently open access under the terms of the Creative Commons Attribution License 4.0 International License

\begin{abstract}
Unemployment and inflation are major problems in macroeconomics. While solving the unemployment problem is a priority for some governments, for others it is bringing inflation under control. Unemployment and inflation surface are two undesirable problems for economies. Governments of countries implement monetary and fiscal policies suited to their aims to solve these problems. The Group 6 (G6) states are countries that have influence in steering the policies of international institutions. In this regard, this study investigated whether there is a relationship between the inflation rate and unemployment in nine randomly selected G6 countries (Australia, Brazil, Canada, France, Germany, Italy, the Russian Federation, Turkey, and the United Kingdom), using data from the period 2009-2017 and applying a panel causality test. According to the Granger causality test, there is a unidirectional causality from inflation rate to unemployment rate. According to the results of the research, bringing inflation under control in these countries is becoming a prior goal. As a result of the policies to bring the inflation under control, the demand for goods and services in the economy decreases. As the aggregate demand for goods and services in the economy decreases, the demand for the workforce decreases as well. In macroeconomic policies there is a relationship between inflation and unemployment. While unemployment increases inflation decreases and while unemployment decreases inflation increases. Our research results also support this. When inflation is intended to be brought under control, it causes unemployment in the economy.
\end{abstract}

Keywords Inflation, Unemployment, Granger
Causality Test

JEL Classification C23, E24, E31

\section{Introduction}

Countries implement certain policies (such as monetary, fiscal, foreign receipts, and income policies) to achieve the objectives they select. Macroeconomic indicators in each country become important in determining which objective to pursue as the priority. The macroeconomic indicators countries set as goals in the policies they implement vary depending on the conditions of the country. While it is important to bring inflation under control, for some countries, it becomes important to increase economic growth, and for others the aim is to decrease unemployment rates. For some countries, in contrast, maintaining the balance of payments and decreasing the foreign trade deficit are among the priority objectives.

Unemployment is the situation, in which individuals with the capacity and desire for employment cannot find jobs. In other words, it is the actual exclusion of labor. Unemployment is generally discussed in three categories: frictional, structural, and cyclical unemployment. The sum of frictional and structural unemployment rates gives the natural rate of unemployment. The natural rate of unemployment is considered to be between 3\% and 5\% globally. If the unemployment rate in an economy is between $3 \%$ and $5 \%$, it can be argued that this economy 
does not have an unemployment problem. According to classical economics, every individual who wishes to work at the prevailing wage level can find jobs, and thus unemployment is voluntary. However, according to Keynes, unemployment is defined as the inability of individuals to find jobs at the prevailing wage level despite their wishes, in other words as involuntary unemployment.

A constant increase in the general level of prices is called inflation. That is, inflation is the increase in the general level of prices in an economy, with a general level of prices higher than the normal level and a decrease in the intrinsic value of money. According to classical economics, the reason for inflation is an increase in the supply of money from the monetary authorities. For Keynes, if the economy is set at liberty, unemployment surfaces due to aggregate demand insufficiency. Keynes stated that the increase in the supply of money would increase the aggregate demand, and this would decrease unemployment and thus increase employment. The monetarist school sees inflation as a monetarist issue. According to monetarist theoreticians, only the money supply can affect current expenditures, incomes, and prices. Unemployment and inflation are considered important problems for many countries. The sum of the unemployment rate and the inflation rate reveals the level of economic dissatisfaction. Therefore, countries wish to minimize, even eliminate, these problems in their own economies; they implement many macroeconomic policies to solve these problems.

The relationship between unemployment and inflation surfaced first with the Phillips model. The Phillips curve was proposed by A. W. Phillips in 1958. Phillips revealed the changes in wages and unemployment rates in the UK from 1861 to 1957 . The analysis he conducted indicated that there was a negative correlation between inflation and unemployment. Phillips emphasized that there was a trade-off between inflation and unemployment. In other words, it is not possible to decrease or increase unemployment and inflation simultaneously. Unemployment decreases when inflation increases or vice versa. However, this negative correlation between inflation and unemployment is not permanently valid. In the short-term, unemployment decreases when inflation increases slightly, but unemployment begins to increase after some time even though inflation remains stable. Therefore, both inflation and unemployment will increase. Although the Phillips model is valid short-term, it loses its validity in the long-term [21].

Following the global recession caused by the worldwide oil crisis in 1974, the rich and powerful countries of the worlds convened in 1975 in Rambouillet, France, and established the G6 group of nations. Later, other nations with large economies, such as Australia, Brazil, Canada, France, Germany, Italy, Russia, Turkey, and the UK, joined this group. Russia was excluded from the group of countries that are members of G6 in 2014 as Russia invaded Crimea in 2014. These countries placed importance on discussing and solving issues such as microeconomic issues, macroeconomic administration, international trade, cooperation with developing countries, employment, environmental problems, crime, human rights, regional security, and cooperation in solving future problems. The G6 countries (Australia, Brazil, Canada, France, Germany, Italy, Russian Federation, Turkey, and the UK) constitute three of the five permanent members of the UN, four of the EU member states, seven of the Organisation for Economic Co-operation and Development (OECD) countries, and the nations with the most influential votes at the International Monetary Fund (IMF). The decisions made by the leaders of the G6 countries play a critical role in steering the policies of international institutions such as the World Bank, the International Monetary Fund, the OECD, the World Trade Organization, and the Northern Atlantic Treaty Organization. This results from the economic power of these countries. Therefore, the relationship between unemployment and inflation was investigated as a macroeconomic indicator for these countries. In this study, a panel causality test was conducted using annual data for the period from 2009 to 2017 for Australia, Brazil, Canada, France, Germany, Italy, Russian Federation, Turkey, and the UK among the G6 countries, since the problems of unemployment and inflation are important for many countries. The test results revealed that there was a unidirectional causality between inflation and unemployment.

\section{Literature Review}

Whereas a cointegration was demonstrated between the rate of unemployment and rate of inflation as a result of the analysis Furuoka [9] carried out with the data relating to the period between 1980 and 2006, such analysis did not find a causality relationship between the two variables. Eita \& Ashipala [8] carried out a study for Namibia with the data relating to the period between 1971 and 2007 and concluded that there is a negative relationship between unemployment and inflation. The results revealed that the Phillips curve is applicable to Namibia. Haug \& King [13] carried out a study for the USA with the data collected in the period between 1952 and 2010 and discovered a positive relationship between inflation and unemployment in the long term. Zaman et al. [32] carried out a study for Pakistan with the data relating to the period between 1975 and 2009 and established a no proportionally negative relationship between inflation and unemployment. In the economy of Pakistan, when unemployment decreases, inflation increases. In the studied periods in Pakistan, there is a long-termed and temporary relationship between inflation and unemployment. 
Kogid et al. [16] conducted a Toda-Yamamoto causality test for Malaysia with the data relating to the period between 1975 and 2007 and determined a unidirectional causality relationship from inflation to unemployment. Meanwhile, there is a cointegration relationship between inflation and unemployment in the long term. These results indicate a trade-off relationship between inflation and unemployment in Malaysia in the studied period. Results of the study carried out by Dritsaki \& Dritsaki [7] for Greece with the annual data relating to the period between 1980-2010 presented that there is a casual relationship between inflation and unemployment in the long term. A causality relationship was not found between unemployment and inflation as a result of the Granger causality test conducted by Al-Zeaud [3] for Jordan with the data relating to the period between 1984 and 2011 whose result showed that there is not a trade-off between the two variables. The error correction model carried out by Furuoka \& Munir [10] for Malaysia with the annual data relating to the period between 1975 and 2004 demonstrated that unemployment has an impact on inflation both in the long term and in the short term. A two-way relationship was discovered between unemployment and inflation in the Granger causality test conducted by Thayaparan [30] for Sri Lanka with the data relating to the period between 1990 and 2012.

The Granger causality test conducted by Sa'idu \& Muhammad [23] for Nigeria with the data relating to the period between 1986-2010 found a unidirectional causality relationship from inflation to unemployment. Alisa [1] tested the validity of the Phillips curve for Russia taking the years 1999-2015 as a basis. Test results revealed that the Phillips test is not valid. The analysis carried out by Orji et al. [20] for Nigeria with the data relating to the period between 1970 and 2011 demonstrated that unemployment is a significant determinant of inflation. There is a positive relationship between the rate of unemployment and inflation in Nigeria. Such results obtained in Nigeria rendered the original proposition about the Phillips curve hypothesis invalid. The analyses carried out by Singh \& Verma [25] for India with the data relating to the period between 2009-2015 determined a reverse relationship between unemployment and inflation in the short term. In other words, an increase in inflation leads to a decrease in unemployment. Results of the Granger causality test carried out by Siyan et al. [27] for Nigeria with the data relating to the period between 1980-2014 revealed a unidirectional relationship between unemployment and inflation. Whereas proof of a trade-off between unemployment and inflation could not be found in the short term as a result of the study carried out by Vermeulen [31] for South Africa with the annual data relating to the period between 2000 and 2015, the study demonstrated that there is a negative relationship between inflation and employment in the long term. The study carried out by Macharia \& Otieno [18] for Kenya with the annual data relating to the period between 1985 and 2015 reached the conclusion that the rate of inflation has a negative impact on the rate of unemployment both in the long and short term.

The time series analysis carried out by Alrayes \& Wadi [2] for Bahrain with the annual data relating to the period between 1980-2015 demonstrated that inflation does not have a significant effect on unemployment. The study carried out by Kasseh [15] for Gambia with the annual data relating to the period between 1991-2015 determined a reverse relationship between unemployment and inflation. The Toda and Yamamoto causality test conducted by Stamatiou \& Dritsaki [26] for Poland with the data relating to the period between 1992 and 2017 revealed a unidirectional relationship from unemployment to inflation. Tenzin [29] used the Autoregressive Distributed Lag (ARDL) model for Butane with the data relating to the period between 1998-2016 and, as a result of the test, found that inflation has a negative relationship with unemployment in the short term but a positive relationship in the long term. Tenzin [29] emphasized that inflation causes uncertainty in the economy and leads to decreased investments in the economy and therefore, will lead to an increase in unemployment in the long term. The Granger causality test conducted by Sasongko \& Huruta [24] for Indonesia with the annual data relating to the period between 1984-2017 found that there is a unidirectional causality relationship from unemployment to inflation.

\section{Data Set and Method}

This study investigated whether there was a relationship between inflation rates (CPI) and unemployment rates (UR) in randomly selected G6 countries (Australia, Brazil, Canada, France, Germany, Italy, the Russian Federation, Turkey, and the UK) with a panel causality test. Logarithms of unemployment and inflation variables were taken. The consumer price index (CPI) was used to determine the inflation rate. Unemployment and inflation data were obtained from the electronic data distribution network of the World Bank. The data set is comprised of annual data from the 2009-2017 period.

\subsection{Panel Unit Root Tests}

Conducting unit root tests in a time series analysis has become popular among researchers and is important to ensure that the results in econometric analyses are statistically significant. In the literature on panel unit root tests, several panel unit root tests, such as those of Quah [22]; Im, Pesaran, \& Shin [14]; Maddala \& Wu [19]; Choi [6]; Harris \& Tzavalis [11]; Levin, Lin \& Chu [17]; Breitung [5] and Harris \& Sollis [12] are described 
(Baltagi \& Kao, [4], p. 2).

In addition, Quah [22] proposed a unit root test in the panel data model, in which the $\mathrm{N}-\mathrm{T}$ ratio was constant, and $\mathrm{N}$ and $\mathrm{T}$ values approached infinity and did not have fixed effects.

Levin and Lin developed this model to allow fixed effects, individual determinant trends, and heterogeneous, serially correlated errors. Levin and Lin acknowledged that $\mathrm{N}$ and $\mathrm{T}$ values approach infinity. However, when the $\mathrm{N}-\mathrm{T}$ ratio approaches zero, $\mathrm{T}$ approaches infinity faster than N (Maddala \& Wu, [19], p. 633). Im et al. [14] argue that the $\mathrm{N}$ value also approaches infinity as the $\mathrm{T}$ value approaches infinity. When the $\mathrm{N}-\mathrm{T}$ ratio is $\mathrm{k}$, with the $\mathrm{k}$ value hypothesized to be a finite and non-negative constant, $\mathrm{T}$ and $\mathrm{N}$ values approach infinity due to cross-vergence.

The stationarity of the variables in our study was determined using the following stationarity tests: Levin, Lin, \& Chu (LLC) [17]; Im, Pesaran, \& Shin (IPS) [14]; ADF; and PP. In all tests, which were first-generation stationarity tests, it was found that the GDP and UR series only showed the constant and did not show a trend. Table 1 shows that the unit root process for the GDP and UR series, with 5\% significance level in the first difference, was stationary for LLC, IPS, ADF-Fisher, ADF, and PP-Fisher tests.

Table 1. Panel Unit Root Tests

\begin{tabular}{cccccccc}
\hline \multirow{2}{*}{ Variables } & Method & I(0) Statistic & Prob $^{*}$ & $\begin{array}{c}\text { I(1) } \\
\text { Statistic }\end{array}$ & Prob $^{*}$ & I(2) Statistic $^{*}$ Prob $^{*}$ \\
\hline \multirow{2}{*}{ LCPI } & Levin, Lin \& Chu t & -1.019 & 0.153 & -5.214 & $0.000^{*}$ & -4.432 & $0.000^{*}$ \\
& Im, Pesaran \& Shin W-stat & 0.614 & 0.731 & -1.508 & 0.065 & -1.668 & $0.047^{*}$ \\
& ADF-Fisher Chi-square & 19.378 & 0.368 & 29.234 & 0.045 & 31.834 & $0.023^{*}$ \\
& PP-Fisher Chi-square & 61.008 & $0.000^{*}$ & 18.164 & 0.444 & 39.864 & $0.002^{*}$ \\
\hline \multirow{2}{*}{ LUR } & Levin, Lin \& Chu t & -3.652 & $0.000^{*}$ & -5.593 & $0.000^{*}$ & -5.333 & $0.000^{*}$ \\
& Im, Pesaran \& Shin W-stat & -0.841 & 0.200 & -1.129 & 0.129 & -1.641 & $0.050^{*}$ \\
& ADF-Fisher Chi-square & 24.285 & 0.145 & 26.329 & 0.092 & 3.972 & $0.029 *$ \\
\hline
\end{tabular}

*Im, Pesaran, \& Shin; ADF-Fisher and PP-Fisher - Null hypothesis: unit root (individual unit root process). Levin, Lin, \& Chu Test - Null hypothesis: unit root (common unit root process). Automatic lag length selection based on modified Schwarz criteria and the Bartlett kernel. 


\subsection{Granger Causality Test}

As the series compared in the implementation have deterministic elements, they are also far from being covariance-stationary. The causal relationships of the series were examined, which were cleansed of deterministic elements, such as seasonal mobility, and rendered stationary by taking the first order differences to provide covariance-stationarity. This is formulated as follows (Şen et al., [28], p. 135):

$$
\begin{array}{r}
\Delta \Delta L C P I_{1 t}= \\
\alpha_{11}+\sum_{l=1}^{P_{1}} \beta_{11 l} \Delta \Delta L C P I_{1 t-l}+\sum_{l=1}^{P_{1}} \delta_{11 l} \Delta \Delta L U R_{1 t-l}+\varepsilon_{11 t}
\end{array}
$$

$$
\begin{aligned}
\Delta \Delta L C P I_{N t}=\alpha_{1 N} & +\sum_{l=1}^{P_{1}} \beta_{1 N l} \Delta \Delta L C P I_{N t-l} \\
& +\sum_{l=1}^{P_{1}} \delta_{1 N l} \Delta \Delta L U R_{N t-l}+\varepsilon_{1 N t}
\end{aligned}
$$

$\triangle \triangle L U R_{1 t}=$ $\alpha_{21}+\sum_{l=1}^{P_{2}} \beta_{21 l} \Delta \Delta L C P I_{1 t-l}+\sum_{l=1}^{P_{2}} \delta_{21 l} \Delta \Delta L U R_{1 t-l}+\varepsilon_{21 t}$

$$
\begin{aligned}
\Delta \Delta L U R_{N t}=\alpha_{2 N} & +\sum_{l=1}^{P_{2}} \beta_{2 N l} \Delta \Delta L C P I_{N t-l} \\
& +\sum_{l=1}^{P_{2}} \delta_{2 N l} \Delta \Delta L U R_{N t-l}+\varepsilon_{2 N t}
\end{aligned}
$$

In the equations above, $\mathrm{N}$ is the number of the countries in the panel $(\mathrm{I}=1,2,3, \ldots, \mathrm{N}), \mathrm{T}$ is the time period $(\mathrm{t}=$ $1,2,3, \ldots, \mathrm{T})$ and "l" is the lag length. The error terms $\varepsilon 1 \mathrm{Nt}, \varepsilon 2 \mathrm{Nt}, \varepsilon 3 \mathrm{Nt}$ are considered to be white noise (having zero mean and fixed covariance).

Table 2. Granger Causality Test

\begin{tabular}{crrr}
\hline Null hypothesis: & Obs & F-Statistic & Prob. \\
\hline & & & \\
$\Delta \Delta$ LUR does not Granger cause $\Delta \Delta$ LCPI & 27 & 0.455 & 0.767 \\
$\Delta \Delta$ LCPI does not Granger cause $\Delta \Delta$ LUR & 4.692 & $0.009 *$
\end{tabular}

$\mathrm{H}_{0}=$ CPI is not the cause of UR

$\mathrm{H}_{1}=\mathrm{CPI}$ is the cause of UR.

Since the probability value is smaller than $5 \%$ in the first hypothesis, $\mathrm{H}_{0}$ is rejected. In other words, there is a unidirectional relationship between CPI and UR.

\section{$\mathrm{H}_{0}=$ UR is not the cause of CPI}

$\mathrm{H}_{1}=$ UR is the cause of CPI.

Since the probability value is greater than $5 \%$ in another hypothesis presented in Table $2, \mathrm{H}_{0}$ is accepted. Therefore, no causal relationship was found between UR and CPI.

The panel Granger causality test results revealed that there is a relationship between the unemployment rate and the inflation rate in selected G6 countries. According to the Granger causality test, a unidirectional causal relationship was found between the inflation rate and the unemployment rate. Governments are implementing policies to bring the inflation rate under control. However, these policies may slow economic growth. When economic growth slows, unemployment may rise. Therefore, policies with the goal of decreasing the inflation rate may, indirectly, cause unemployment.

Results that are consistent with the studies in the literature carried out by Eita \& Ashipala [8], Zaman et al. [32], Kogid et al. [16], Dritsaki \& Dritsaki [7], Sa'idu \& Muhammad [23], Singh \& Verma [25], Siyan et al. [27], Macharia \& Otieno [18], Kasseh [15] and inconsistent with the studies carried out by Furuoka [9], Haug \& King [13], Al-Zeaud [3], Furuoka \& Munir [10], Thayaparan [30], Alisa [1], Orji et al. [20], Vermeulen [31], Alrayes \& Wadi [2], Stamatiou \& Dritsaki [26], Sasongko \& Huruta [24] were obtained.

Most of the studies carried out in the literature tested whether the classic Phillips curve is valid for the country economies they investigated. However, in our study, the relationship between inflation and unemployment -which are among the significant macroeconomic variables of countries that are dominant in the world economy- rather than the classic Phillips curve, was investigated. As a result of the test carried out, unidirectional causality relationship from inflation to unemployment was found. This result shows that those countries adopt controlling inflation as a more preferred objective than solving the unemployment problem. As a result of the policies implemented to take inflation under control, aggregate demand for goods and services decreases in the economy. Growth rate of countries' economies is slowing down due to the decrease in the aggregate demand for goods and services in the economy and this leads to increased unemployment.

\section{Summary and Concluding Remarks}

Problems such as inflation and unemployment have existed in almost all economies throughout history. Therefore, inflation and unemployment have become the most discussed problems in the economic research literature. The decisions taken by the leaders of G6 countries play a critical role in steering the policies of international institutions. In this regard, this study investigated whether there is a relationship between the inflation rate and the unemployment in nine randomly selected G6 countries (Australia, Brazil, Canada, France, Germany, Italy, the Russian Federation, Turkey, and the United Kingdom), using data from the 2009-2017 period with a panel causality test. According to the Granger causality test, there is a unidirectional causality relationship between inflation rates and unemployment rates. 
Inflation affects unemployment because many governments implement contractionary fiscal and monetary policies to bring inflation under control. When inflation is high, the purchasing power and effect of the national currency decreases. Thus, the aggregate demand for goods and services decreases in a high-inflation environment. In such cases, one of the policies to implement is a contractionary fiscal policy; public expenditure should be reduced in the fight against inflation. Aggregate demand should be turned into aggregate supply level in the short term by reducing public expenditure. Another possible fiscal policy is to reduce transfer payments. To combat inflation, changes in tax policies should be made, in addition to reducing public expenditure and transfer payments. Since employment is high in inflationist periods, the tax burdens of individuals should be increased as expenditure increases. If the state resorts to a voluntary increase in tax rates as a measure to combat inflation, individuals with high saving potential would become unwilling to make savings and investments. As taxes are taken to create a budgetary surplus in fighting inflation, and taxpayers are more interested in the taxes they pay than the benefits they receive from public expenditure, the resistance of taxpayers to the tax policy would increase. In consequence, economic growth would slow due to the decrease in the aggregate demand for goods and services, and this would cause unemployment to increase. France, a G6 member, is implementing a contractionary fiscal policy by increasing taxes and reducing public expenditure. In the UK economy, too, the tax rate could be increased and the fiscal deficit could be reduced by reducing public expenditure to solve the inflation problem. In Turkey, first public expenditure was reduced using an inflation-fighting fiscal policy, then transfer payments were reduced and public income was increased. Tax income, especially from taxes levied on goods and services and foreign trade, was increased. Consequently, fiscal deficits decreased, and the policy has become influential in decreasing inflation.

Monetary policy, determined by the central bank jointly with the state, is implemented via open market operations, required reserves, and rediscount policy instruments. With high interest rates, one of the monetary policies implemented in fighting inflation, the aggregate demand for goods and services is decreased and aggregate expenditure is reduced. By implementing this policy, economic growth is reduced and inflation is decreased. High interest rates reduce consumer expenditure and prevent consumers from borrowing and spending. At the same time, high interest rates make saving attractive, increase the value of the currency, and cause lower exports and higher imports. In the UK, the government decreased the fiscal deficit by implementing high interest rates to control inflation via money supply controls and succeeded in decreasing inflation by preferring economic recession. Monetarism has been abandoned since the connection between money supply and inflation is weaker than expected. The Central Bank of the Republic of Turkey has determined the objectives of decreasing the money supply in the markets via monetary policy instruments and bringing inflation under control. To achieve these aims, it is selling open market operations, and increasing the rediscount rates, required reserve ratios, and interest rates. In other words, it is decreasing the demand for goods and services by reducing money supply and increasing the trend for saving. If the inflation in a country is high, then the aggregate demand for goods and services will increase due to policies implemented to bring inflation under control, and this will result in lower production and higher unemployment. Policies to slow economic growth rate and inflation may cause unemployment to increase.

\section{REFERENCES}

[1] Alisa, M. (2015). The Relationship between Inflation and Unemployment: A Theoretical Discussion about the Phillips Curve. Journal of International Business and Economics, 3(2), 89-97.

[2] Alrayes, S. E., \& Wadi, R. M. A. (2018). Determinants of Unemployment in Bahrain. International Journal of Business and Social Science, 9(12), 64-74.

[3] Al-Zeaud, H. A. (2014). The Trade-Off between Unemployment and Inflation Evidence from Causality Test for Jordan. International Journal of Humanities and Social Science Special Issue 4, No. 4, 103-111.

[4] Baltagi, B. H., \& Kao, C. (2000). Nonstationary Panels, Cointegration in Panels and Dynamic Panels: A Survey. Center for Policy Research Working Papers, No. 16.

[5] Breitung, J. (2000). The Local Power of Some Unit Root Tests for Panel Data. Advances in Econometrics, 15, 161-177.

[6] Choi, I. (2001). Unit Root Tests for Panel Data. Journal of International Money and Finance, 20, 249-272.

[7] Dritsaki, C., \& Dritsaki, M. (2012). Inflation, Unemployment and the NAIRU in Greece. Procedia Economics and Finance, 1, 118-127.

[8] Eita, J. H., \& Ashipala, J. M. (2010). Determinants of Unemployment in Namibia. International Journal of Business and Management, 5(10), 92-104.

[9] Furuoka, F. (2008). Unemployment and Inflation in the Philip-pines: New Evidence from Vector Error Correction Model. Philippine Journal of Development, 35(1), 93-106.

[10] Furuoka, F., \& Munir, Q. (2014). Unemployment and Inflation in Malaysia: Evidence from Error Correction Model. Malaysian Journal of Business and Economics, 1(1), 35-45.

[11] Harris, R. D. F., \& Tzavalis, E. (1999). Inference for Unit Roots in Dynamic Panels Where the Time Dimension is 
Fixed. Journal of Econometrics, 91, 201-226.

[12] Harris, R., \& Sollis, R. (2003). Applied Time Series Modelling and Forecasting. John Wiley: West Sussex.

[13] Haug, A. A., \& King, I. P. (2011). Empirical Evidence on Inflation and Unemployment in the Long Run. University of Otago Economics Discussion Papers, No. 1109, https://www.otago.ac.nz/economics/research/otago076667. pdf.

[14] Im, K. S., Pesaran, M. H., \& Shin, Y. (2003). Testing for Unit Roots in Heterogeneous Panels. Journal of Econometrics 115(1), 53-74

[15] Kasseh, P. A. (2018). The Relation between Inflation and Unemployment in the Gambia: Analysis of the Phillips Curve. Journal of Global Economics, 6(2), 1-7.

[16] Kogid, M., Asid, R., Mulok, D., Lily, J., \& Loganathan, N. (2012). Inflation-Unemployment Trade-Off Relationship in Malaysia. Asian Journal of Business and Management Sciences, 1(1), 100-108.

[17] Levin, A., Lin, C-F., \& Chu, C-S. (2002). Unit Root Tests in Panel Data: Asymptotic and Finite-Sample Properties. Journal of Econometrics, 108, 1-24.

[18] Macharia, M. K., \& Otieno, A. (2017). Effect of Inflation on Unemployment in Kenya. International Journal of Science and Research, 6(6), 1980-1984.

[19] Maddala, G.S., \& Wu, S. (1999). A Comparative Study of Unit Root Tests with Panel Data and a New Simple Test. Oxford Bulletin of Economics and Statistics, 61(1), 631652.

[20] Orji, A., Anthony-Orji, O. I., \& Okafor, J. C. (2015). Inflation and Unemployment Nexus in Nigeria: Another Test of the Phillip's Curve. Asian Economic and Financial Review, 5(5), 766-778.

[21] [21] Phillips, A.W. (1958). The Relation between Unemployment and the Rate of Change of Money Wage Rates in the United Kingdom, 1861-1957. Economica, 25(100), 283-299.

[22] Quah, D. (1994). Exploiting Cross Section Variation for Unit Root Inference in Dynamic Data. Economics Letters, 44, No. 1-2, 9-19.
[23] Sa'idu, B. M., \& Muhammad, A. A. (2015). Do Unemployment and Inflation Substantially Affect Economic Growth?. Journal of Economics and Development Studies, 3(2), 132-139.

[24] Sasongko, G., \& Huruta, A. D. (2019). The Causality between Inflation and Unemployment: The Indonesian Evidence. Business: Theory and Practice, 20, 1-10.

[25] Singh, D., \& Verma, N. (2016). Tradeoff between Inflation and Unemployment in the Short Run: A Case of the Indian Economy. International Finance and Banking, 3(1), 77-96.

[26] Stamatiou, P., \& Dritsaki, C. (2018). "Inflation, Unemployment and the NAIRU in Poland", in Advances in Time Series Data Methods in Applied Economic Research, (ed. Tsounis, N., \& Vlachvei, A.), 1 st ed, Springer International Publishing, pp. 159-176.

[27] Siyan, P., Adegoriola, A. E., \& Adolphus, J. A. (2016). "Unemployment and Inflation: Implication on Poverty level in Nigeria". MPRA, No. 79765. https://mpra.ub.uni-muenc hen.de/79765/1/MPRA_paper_79765.pdf.

[28] Şen, H., Kaya, A., \& Alpaslan, B. (2018). Education, Health, and Economic Growth Nexus: A Bootstrap Panel Granger Causality Analysis for Developing Countries. Sosyoekonomi, 26(36), 125-144.

[29] Tenzin, U. (2019). The Nexus Among Economic Growth, Inflation and Unemployment in Bhutan. South Asia Economic Journal, 20(1). 94-105.

[30] Thayaparan, A. (2014). Impact of Inflation and Economic Growth on Unemployment in Sri Lanka: A Study of Time Series Analysis. Global Journal of Management and Business Research: B Economics and Commerce, 13(5), 44-54.

[31] Vermeulen, J. C. (2017). Inflation and Unemployment in South Africa: Is the Phillips Curve Still Dead?. Southern African Business Review, 21(1), 20-54.

[32] Zaman, K., Khan, M. M., Ahmad, M., \& Ikram, W. (2011). Inflation, Unemployment and the NAIRU in Pakistan (1975-2009). International Journal of Economics and Finance, 3(1), 245-254. 